\title{
Implementasi Asesmen Diagnostik Dalam Upaya Meningkatkan Hasil Belajar Matematika di SD Kota Banjarbaru Kalimantan Selatan
}

\author{
Oleh: Darmiyati *
}

Abstrak: Penelitian ini bertujuan untuk memverifikasi apakah pelaksanaan asesmen diagnostik melalui penilaian tes, non tes, dan remedial dapat meningkatkan hasil belajar matematika di Sekolah Dasra (SD). Penelitian ini dilaksanakan di kelas 3 SDN 04 Banjarbaru Utara 4, dengan jumlah sampel 34 orang siswa. Jenis penelitian yang digunakan adalah penelitian tindakan kelas. Penelitian ini dibantu oleh tiga orang kolaborator yang mengikuti langkah-langkah pra observasi, perencanaan tindakan, pelaksanaan tindakan dan refleksi. Penelitian ini dilaksanakan empat siklus, subjek penelitian ini guru dan siswa, data dikumpulkan melalui tes, kuesioner sikap, observasi perilaku siswa, dan wawancara. Analisis data yang digunakan dalam penelitian ini adalah kualitatif dan kuantitatif. Hasil penelitian menunjukkan bahwa hasil belajar siswa meningkat setelah setiap topik pembelajaran diberikan asesmen diagnostik, berupa pemberian tes, remedial, dan non tes berupa kuesioner sikap siswa, observasi perilaku siswa mengikuti pembelajaran matematika.

Kata Kunci: asesmen diagnostik, remedial, sikap siswa, perilaku siswa, dan hasil belajar matematika.

\section{Pendahuluan}

\subsection{Latar Belakang Masalah}

Pembangunan Indonesia antara lain diarahkan untuk meningkatkan kualitas sumber daya manusia (SDM), karena sumber daya manusia yang berkualitas sangat diperlukan dalam pembangunan bangsa khususnya pembangunan dibidang pendidikan. Sektor pendidikan memegang peranan yang sangat penting, dalam mengantisipasi dan menjawab tantangan masa depan (Era Globalisasi), melalui pendidikan akan

* Darmiyati adalah dosen PGSD pada FKIP Universitas Lambung Mangkurat 
menghasilkan tenaga terampil dalam bidangnya masing-masing atau dengan kata lain lulusan dari proses pendidikan, dapat diwujudkan sumber daya manusia yang berkualitas.

Pendidikan menjadi tumpuan harapan baik yang menyangkut perkembangan ilmu pengetahuan teknologi dan seni, maupun perkembangan pendidikan itu sendiri.

Matematika sebagai salah satu kemampuan dasar yang harus dimiliki siswa mempunyai peranan penting dalam mengembangkan ilmu dan teknologi, tidak hanya dalam dibidang eksakta tapi juga dalam bidang ilmu pengetahuan lainpun membutuhkan matematika. Disisi lain siswa merasa kesulitan dalam belajar matematika, dan mereka menganggap konsep matematika sangat sulit dibandingkan dengan pelajaran lainnya. Upaya untuk meningkatkan hasil belajar matematika dikembangkan terus menerus oleh Pemerintah maupun kalangan swasta melalui penyempurnaan kurikulum, penyedian buku ajar, penataran, alat peraga, dan peningkatan sarana prasarana pendidikan.

Kenyataannya pengajaran matematika sekarang ini masih mempunyai kelemahan menyebabkan kurangnya penguasaan siswa terhadap materi yang diajarkan.
Kurangnya penguasaan siswa ini ditunjukkan oleh hasil penelitian "The Third International Mathematics and Science Study-Rpeat (TIMSS-R 1999) (Mullis L Marten 2000), melaporkan bahwa penguasaan siswa dalam bidang studi matematika menempati urutan ke-34 dari 38 negara yang disurvai di Asia, Australia, dan Afrika (Puspendik, 2003: 6-7). Di Kota Banjarbaru berdasarkan hasil studi awal yang dilakukan diperoleh bahwa hasil belajar siswa pada pelajaran matematika tergolong rendah dari pada bidang studi lainnya. Data hasil Ebtanas murni pelajaran matematika di SD Negeri 04 Banjarbaru adalah sebesar 4,57 (Laporan Ebtanas SD Rayon Banjarbaru Kantor Wilayah Depdiknas).

Kebijaksanaan Pendidikan Tingkat Nasional maupun Wilayah cenderung bersikap makro, masih belum menangkap masalah yang timbul di SD lebih-lebih di kelas secara individual, termasuk permasalahan yang muncul di kelas, dan adanya siswa yang mengalami kesulitan dalam belajar matematika atau dengan istilah penilaian hanya dari segi kognitif saja, sedangkan faktor non kognitif kurang diperhatikan. Berdasarkan informasi guru bahwa saat ini penilaian hasil belajar matematika 
di sekolah hanya dari segi kognitif saja berupa penilaian ulangan harian, nilai tes formatif, dan nilai sumatif. Sedangkan penilaian kognitif seperti sikap siswa, perilaku siswa mengikuti pelajaran matematika belum pernah dilaksanakan karena dianggap sebagai pemborosan waktu, tenaga, biaya, dan banyaknya target kurikulum yang harus diselesaikan dalam batas waktu yang telah ditentukan.

Kegiatan evaluasi hasil belajar terdiri dari kegiatan pengukuran dan penilaian. Penilaian didahului oleh pengukuran, dan pengukuran tidak berarti apa-apa kalau tidak dilanjuti dengan penilaian. Untuk dapat melakukan penilaian yang tepat hendaknya didasari hasil pengukuran yang tepat pula. Kegiatan pengukuran memerlukan alat ukur dalam hal ini adalah tes hasil belajar. Hasil evaluasi belajar yang diperoleh ini dapat dipakai sekolah untuk melihat sejauh mana kondisi belajar yang diciptakannya terlaksana dengan baik, tujuan utama melaksanakan evaluasi dalam pembelajaran adalah untuk mendapatkan informasi yang akurat mengenai tujuan pembelajaran yang diterima siswa, sehingga dapat diupayakan tindak lanjutnya, salah satu upaya menindak lanjuti hasil evaluasi yang kurang memuaskan adalah dengan pemberian asesmen diagnostik. Asesmen diagnostik merupakan penilaian yang diberikan pada siswa sebagai akibat dari hasil tes formatif, mengenai kesulitan belajar yang di alami siswa, dan menentukan faktor-faktor yang menyebabkan terjadinya kesulitan belajar, serta menetapkan cara mengatasi kesulitan tersebut. Penilaian dapat dilakukan dengan cara tes dan non tes. Keinginan untuk mengetahui pokok bahasan mana dari hasil tes formatifyang belum dikuasai siswa, dan untuk memverifikasikan apakah pelaksanaan asesmen diagnostik dapat memperbaiki proses pembelajaran sekaligus sistem penilaiannya melalui tes, non tes serta remedial sehingga dapat meningkatkan hasil belajar siswa. Dirasa perlu untuk diteliti.

\subsection{Perumusan Masalah}

Apakah penerapan asesmen diagnostik melalui penilaian tes, remedial, dan non tes dapat meningkatkan efektivitas pembelajaran matematika di sekolah dasar?

\subsection{Tujuan Penelitian}

Penelitian ini bertujuan untuk memverifikasi apakah pelaksanaan asesmen diagnostik melalui penilaian tes, remedial, dan non tes dapat 
meningkatkan meningkatkan efektivitas pembelajaran matematika di sekolah dasar?

\section{Kajian Literatur}

\subsection{Hasil Belajar Matematika .}

Higgins memberikan pengertian bahwa matematika adalah ilmu yang mempelajari konsep, simbol serta hubungan antara konsep dan simbol tersebut (Higgens, 1983: 4). Lebih tegas lagi Russel dalam Ruseffendi menyatakan bahwa "Mathematics is the queen of the sciences" matematika adalah ratunya ilmu (Ruseffendi, 1988: 200).

Ada empat sasaran pokok yang ingín dicapai dalam pelajaran matematika yaitu, fakta, keterampilan, konsep, dan prinsip (Bell, 1981:108109). Tujuan pendidikan matematika yang termuat dalam kurikulum pendidikan dasar adalah: "Mempersiapkan siswa agar sanggup menghadapi perubahan keadaan di dalam kehidupan dan di dunia yang selalu berkembang, melalui latihan bertindak atas dasar pemikiran secara logis, rasional, kritis, cermat, jujur, dan efektif. Serta mempersiapkan siswa agar dapat menggunakan matematika dan, pola pikir matematika dalam kehidupan sehari-hari, dan dalam mempelajari berbagai ilmu pengetahuan" (Kurikulum, 1994: 34).
Menilai berhasil tidaknya siswa dalam pembelajaran perlu diukur melalui tes hasil belajar. Hasil belajar adalah tingkah laku yang diukur dengan tes mengenai bidang studi yang dipelajari, berupa pengetahuan dan keterampilan dari program belajar, pengetahuan ditunjukkan oleh informasi yang tersimpan dalam pikiran, sedangkan keterampilan ditunjukkan dengan aksi atau reaksi yang dilakukan seseorang dalam mencapai tujuan (Romiszowski, 1981: 241). Untuk mencapai tingkat hasil belajar yang bermutu yang mendatangkan kepuasan bagi siswa, maka haruslah suasana belajar yang stabil, bekerja keras untuk mempelajari setiap kajian materi yang sedang dipelajari (Robert S. Feldman, 1989: 250). Indikator keberhasilan belajar mengajar antara lain apabila daya serap terhadap bahan pelajaran yang diajarkan mencapai prestasi tinggi, baik secara individu maupun kelompok, perilaku dalam Tujuan Instruksional Khusus (TIK) telah dicapai siswa baik individu maupun kelompok (Usman dan Setiawati, 1993: 8).

Berdasarkan berbagai pendapat dan pemikiran para ahli yang telah dikemukakan di atas dapat disimpulkan bahwa, yang dimaksud dengan hasil belajar matematika 
adalah penguasaan siswa terhadap materi pelajaran, sebelumnya memperoleh pengalaman belajar yang diperlihatkan siswa melalui nilai tes yang diberikan guru.

\section{2 Pengertian Asesmen Diagnostik dalam \\ Pembelajaran Matematika}

Menurut Aiken bahwa asesmen merupakan karakteristik seseorang dengan mengakses tingkah laku manusia dan proses mental dapat dilakukan dengan cara observasi, interview, skala rating, chick lish, teknik proyektif dan tes (Aiken, 1997: 454). Dalam konteks pembelajaran Edwards dan Kninght menegaskan bahwa asesmen sebagai pengendali pengajaran merupakan suatu kegiatan di mana guru mencatat apa yang bisa dilakukan dan apa yang tidak bisa dilakukan siswa, sehingga dapat dibuat langkah kerja berikutnya (Edwars dan Kninght, 1994: 106).

Secara tegas Ecclestone, mengemukakan bahwa Asesmen terkait pula dengan diagnosa belajar menyediakan informasi terutama sekali untuk siswa dan guru dalam membantu proses pembelajaran. Dengan memanfaatkan pengalaman sebelumnya dan kemampuankenampuan yang diperoleh sebelum menulai program (Ecclestone, 1996:
10). Mengingat pentingnya hal ini dilaksanakan dalam kegiatan pembelajaran maka Linn, dan Gronlund menegaskan bahwa asesmen diagnostik disusun untuk mengkaji kesulitan pembelajaran yang belum terpecahkan dengan asesmen formatif (Linn, Norman, Gronlund, 1995: 15).

Pada praktiknya asesmen diagnostik di kelas memiliki dua kawasan, (1) untuk mengidentifikasikan target pembelajaran yang belum dikuasai siswa, (2) untuk menemukan penyebab-penyebab atau alasan-alasan yang mungkin membuat siswa belum dapat menguasai target-target pembelajaran. Sedangkan pada pelaksanaannya pengajaran dan diagnosa kesulitan belajar berjalan secara bersamaan (Nitko, 1996 : 284-285). Ecclestone menyatakan bahwa asesmen diagnostik bukan hanya berhubungan dengan tes dalam pembelajaran, melainkan lebih luas lagi digunakan berkaitan dengan tes kemampuan awal di sekolah untuk literatur dan kemampuan numerik, digunakan sebagai bagian dari proses bimbingan informal yang bertujuan untuk membantu siswa menentukan pilihannya sebelum menerapkan kedalam program yang partikular (Ecclestone, 1996: 71). 
Berdasarkan acuan teori dan pendapat yang dikemukakan di atas maka dapatlah ditarik pemahaman bahwa yang dimaksud dengan asesmen diagnostik dalam pembelajaran matematika pada penelitian ini adalah penilaian yang diberikan pada siswa sebagai akibat dari hasil tes formatif mengenai kesulitan belajar yang dialami siswa. Penilaian dilakukan dengan cara tes, non tes, dan remedial. Tes meliputi tes diagnostik awal, dan tes setiap topik pembelajaran, sedangkan non tes meliputi sikap siswa terhadap pembelajaran matematika, dan observasi perilaku siswa mengikuti pelajaran matematika. Penilaian diberikan sebagai bahan dalam rangka memberikan bimbingan pada siswa yang mengalami kesulitan belajar matematika .

\subsection{Pelaksanaan Asesmen \\ Diagnostik dalam \\ Pembelajaran Matematika}

\subsubsection{Tes Diagnostik Awal}

Tes diagnostik menurut Ebel adalah rancangan untuk mengetahui kekurangan-kekurangan yang khusus atau kegagalan-kegagalan dalam belajar pada beberapa subjek atau pelajaran seperti membaca dan aritmatika (Ebel, 1979:375). Pendapat senada dinyatakan oleh Gronlund tes diagnostik adalah tes yang dirancang untuk mengetahui sebab kegagalan peserta didik dalam belajar (Gronlund, 1990: 13).

Stanley dalam Syamsudin (2003: 309) menyatakan secara rinci langkahlangkah diagnosis kesulitan belajar sebagai berikut: (1) identifikasi kasus, (2) lokalisasi jenis dan sifat kesulitan, (3) menemukan faktor penyebabnya faktor internal dan eksternal. (4) prognosis, yaitu langkah untuk mengetimasi, memperkirakan apakah kesulitan tersebut dapat dibantu atau tidak, dan (5) terapi, yaitu langkah untuk menemukan berbagai alternatif kemungkinan cara yang dapat ditempuh dalam rangka penyembuhan kesulitan tersebut meliputi pengajaran remedial, transfer atau referal.

Berdasarkan deskripsi teori dan pendapat di atas yang dimaksud tes diagnostik awal dalam penelitian ini adalah tes yang diberikan kepada siswa untuk mengetahui kesulitan siswa terhadap materi keterkaitan yang telah diberikan pada caturwulan sebelumnya, sebagai dasar prasyarat untuk mengikuti pelajaran berikutnya dalam bentuk pilihan ganda. Tes dibuat berdasarkan tingkat kognitif siswa meliputi pengetahuan, pemahaman, aplikasi, analisis, sintesis, dan evaluasi. Materinya 
memuat penjumlahan, pengurangan, penjumlahan dan pengurangan, perkalian, pembagian, pengerjaan hitung campuran, dan pecahan, bangun datar sudut, persegi dan persegi panjang.

\subsubsection{Tes setiap Topik}

\section{Pembelajaran (Formatif)}

Pembelajaran dilukiskan sebagai upaya orang yang bertujuan untuk membantu orang lain belajar. Dalam pembelajaran titik beratnya bukan hal mengajar, melainkan pada semua kejadian yang dapat berpengaruh secara langsung terhadap belajar (Bell Gradler, 1994: 205).

Bila ditinjau dari fungsi guru sebagai pengelola dan pelaksana pembelajaran memiliki empat fungsi pokok yang merupakan ciri pekerjaannya yaitu (1) merencanakan, (2) mengorganisasikan, (3) memimpin, dan (4) mengawasi (Davies, 1971:22). Pembelajaran akan efektif jika sesuai dengan minat kebutuhan, perkembangan, dan perbedaan individu setiap siswa. Hal ini sesuai dengan pendapatnya Bredekamp, pembelajaran hendaknya disesuaikan dengan dua kesesuaian, yaitu; (1) kesesuaian dengan usia, dan (2) individu. (Bredekamp, 1987: 2). Collins dan Dixson (1991) mengemukakan bahwa pembelajaran terpadu ini mengacu pada pendekatan inkuari di mana siswa terlibat secara aktif dalam perencanaan, eksplorasi, gagasan hingga mengembangkan minat pribadi yang berkaitan dengan topik yang dibahas (Collin and Dixson, 1991:6).

Karakteristik dari pembelajaran terpadu meliputi holistik, bermakna, otentik, dan aktif(Anonim, 1996/1997: 3-4). Menurut Fogarty Ada sepulụh model pendekatan pembelajaran terpadu yang dapat dikembangkan kepada siswa yaitu: (1) fragmented, (2) connected, (3) nested, (4) sequenced, (5) shared, (6) webbed, (7) threaded, (8) integrated, (9) immersed, dan (10) networked (Fogarty,1991: xv).

Hasil tes formatif dapat menghasilkan keputusan tentang kekuatan dan kelemahan dari suatu sistem pembelajaran yang dikembangkan dengan maksud merevisi dan memperbaiki agar menjadi lebih efektif dan menarik (Tessmer, 1995: 11).

Hasil pembelajaran akan lebih baik jika dilaksanakan bersama-sama secara kelompok melalui tutor sebaya dengan bimbingan guru dari pada belajar sendiri (McKeachie, 1994: 146). Siswa dikategorikan menghasilkan tingkat keberhasilan baik (minimal) apabila bahan pelajaran 
yang dikuasainya antara $66 \%$ sampai dengan 75\% (Djamarah, 2000: 97).

Berdasarkan deskripsi teori dan pendapat di atas yang dimaksud dengan tes setiap topik pembelajaran dalam penelitian ini adalah tes yang diberikan setelah siswa mengikuti setiap topik pembelajaran. Melalui pendekatan pembelajaran terpadu model connected, dan tutor sebaya, materinya meliputi bilangan dan lambang bilangan, nilai tempat, penjumlahan, pengurangan, perkalian, pembagian, hitung campuran, dan materi uang. Hasil tes siswa yang mendapat skor kurang dari 75 atau penguasaan materi kurang dari $75 \%$, akan diberikan tindakan melalui asesmen diagnostik.

\subsection{Sikap Siswa terhadap Pembelajaran Matematika}

Sikap sebagai suatu sistem yang menetap dalam diri individu, berupa penilaian yang bersifat positif dan negatif yakni kecenderungan untuk menyetujui dan menolak. Sikap positif akan terbentuk atau timbul apabila rangsangan yang datang pada seseorang memberi pengalaman yang menyenangkan, dan sikap negatif akan timbul bila rangsangannya memberi pengalaman yang tidak menyenangkan (Crutchfield dan Ballachey, 1988: 177).
Ada beberapa karakteristik untuk melihat konteks sikap; pertama ia berada pada komponen kognitif, afektif, dan konatif (Crutchfield and Ballachey, 1988: 146). Pada konteks pembelajaran setiap guru bertanggung jawab mengembangkan sikap positif terhadap materi matematika pada semua siswa yang akan bermanfaat untuk memecahkan masalah pada kehidupannya (Anghileri, 1995:9). Selain mengembangkan sikap positif, kedudukan evaluasi dalam pembelajaran merupakan hal yang sangat penting dan tidak bisa terpisahkan dari kegiatan pembelajaran. Karena pada pelaksanaannya siswa yang bersikap senang kepada matematika, sikapnya itu tentu mempengaruhi tingkah lakunya terhadap matematika (Hudoyo, 1990: 99). Berdasarkan teori dan pendapat yang telah dikemukakan di atas maka dapatlah ditarik suatu pemahaman bahwa yang dimaksud dengan sikap siswa terhadap pembelajaran matematika adalah faktor intern yang mempengaruhi siswa dan merupakan perwujudan dari kognisi (pengetahuan), afeksi (perasaan), dan konasi (kecenderungan) bertindak dalam pembelajaran matematika, yang disajikan dan dikembangkan oleh guru meliputi; materi pembelajaran, aktivitas guru, alat bantu pembe- 
lajaran, dan evaluasi disertai dengan perasaan positif dan negatif.

\subsection{Perilaku Siswa Mengikuti Pelajaran Matematika}

Perilaku merupakan perubahan perangai yang telah terjadi pada masa pertumbuhan (masa kecil) secara jelas, dan pada saat itulah terjadinya proses pendataan, pengukuran dan pemilikan spesifikasi-spesifikasi perangai yang muncul secara menetap (Carnoy, 1995: 78). Pada praktiknya perilaku seseorang mengacu pada kegiatan yang dapat diobservasi, dan dapat dipelajari secara benar yang ada pada diri seseorang (Fishbein and Ajzen, 1975 : 13). Belajar merupakan perubahan tingkah laku dan kemampuan seseorang yang relatif berlangsung lama, dan perubahan itu bukan akibat dari pertumbuhan saja (Gagne, 1977 : 3). Hudoyo mengata-kan belajar dapat dipengaruhi oleh berbagai faktor individu seperti sikap, minat, perhatian, pengamatan, dan intelegensi (Hudoyo, 1988: 8). Berdasarkan deskripsi teori dan pendapat di atas dapatlah dipahami bahwa perilaku siswa mengikuti pclajaran matematika yang dimaksud dalam penelitian ini adalah aktivitas atau kegiatan siswa berupa tindakan nyata yang dapat diamati, sebagai hasil interaksi siswa dengan ling-kungannya meliputi ketekunan, dan keaktivan siswa baik dalam mengikuti pelajaran maupun melaksanakan tugas matematika diobservasi sewaktu pembelajaran matematika berlangsung.

\section{Metodologi Penelitian}

3.1 Penelitian ini dilaksanakan di SDN 04 Banjarbaru Utara Kota Banjarbaru Kal Sel. Subjek utama penelitian ini adalah 34 siswa kelas III SD, dan guru yang mengajar matematika sebagai subjek pendukung. Desain penelitian acuannya secara umum model The Action Research Cycle langkah-langkahnya tercermin dalam Reconnaissance, Action, Reflecting. Prosedur Penelitian yang dilaksanakan mengacu pada skema Action Research Model Elliot (1) pra observasi, (2) rencana umum tindakan, (3) tindakan, (4) observasi, dan (5) refleksi.

3.2 Instrumen yang digunakan: Tes meliputi Tes Diagnostik Awal, Tes Hasil Belajar, Non Tes meliputi: Sikap siswa terhadap pembelajaran matematika dan Observasi perilaku siswa mengikuti pelajaran matematika. Teknik pengumpulan data instrumen tes, kuesioner, observasi, dokumenter, dan foto. Analisis data yang digunakan dalam penelitian ini kualitatif dan kuantitatif (mixed). 
4. Hasil Penelitian dan Bahasan

4.1 Siklus Pertama : Materi

Bilangan dan Lambang

Bilangan

4.1.1 Pra observasi (Reconnaissance)

Kegiatan penelitian ini diawal dengan memberikan tes sebelum pembelajaran matematika berlangsung, tujuannya untuk mengetahui pokok bahasan apa saja siswa mengalami masalah dalam pelajaran tersebut.
Jumlah pertanyaan sebanyak 40 butir dalam bentuk pilihan ganda. Hasil tes ini menunjukkan bahwa siswa yang mengalami kesulitan banyak kesulitan pada pokok bahasan bilangan dan lambangnya, penjumlahan dan pengurangan, bilangan bulat dan perhitungan uang, serta perkalian dan pembagian.

Hasil kesepakatan peneliti dan guru sebagai kolaborator, materi yang belum dikuasai siswa diulang kembali

\section{Langkah- Langkah Desain Penelitian}

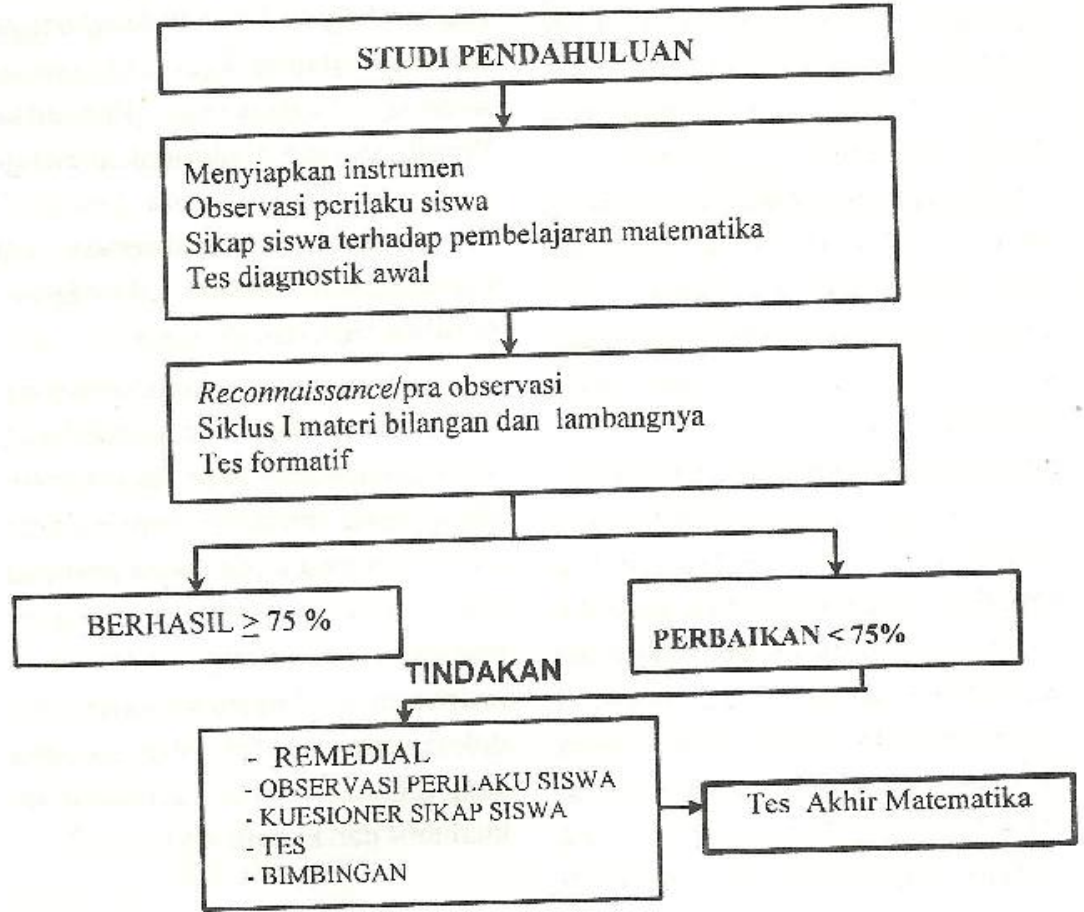


pada kegiatan pembelajaran matematika. Hasil temuan dan pemantauan sewaktu pra observasi dapat terlihat bahwa sebagian besar siswa kurang memperhatikan pelajaran yang diberikan, ada yang meminjam alat tulis pada temannya, sehingga kawannya terganggu, kurang konsentrasi, kurang bersemangat, dan bersifat pasif. Sewaktu mengerjakan tugas diantara siswa ada yang keliru, dan kurang teliti dalam menuliskan nama dan lambang bilangan.

Hasil pra observasi menunjukkan pula bahwa masalah ini muncul bukan hanya dari segi siswa saja namun juga dari segi guru. Dilihat sewaktu pembelajaran berlangsung guru kurang memberi kesempatan bertanya kepada siswa, yang aktif hanya guru, pembelajaran kurang menarik karena tidak menggunakan alat peraga, sehingga anak kurang memperhatikan pembelajaran yang diberikan. Akhimya setelah diberikan tes formatif terdapat siswa yang mengalami kesulitan dalam menjawab pertanyaan tersebut. Hasil penguasaan materi dan jumlah siswa yang bermasalah dan tidak bermasalah dapat dilihat pada Tabel 1 .

\section{Tabel 1 Penguasaan Materi Berdasarkan Persentase Jumlah Siswa}

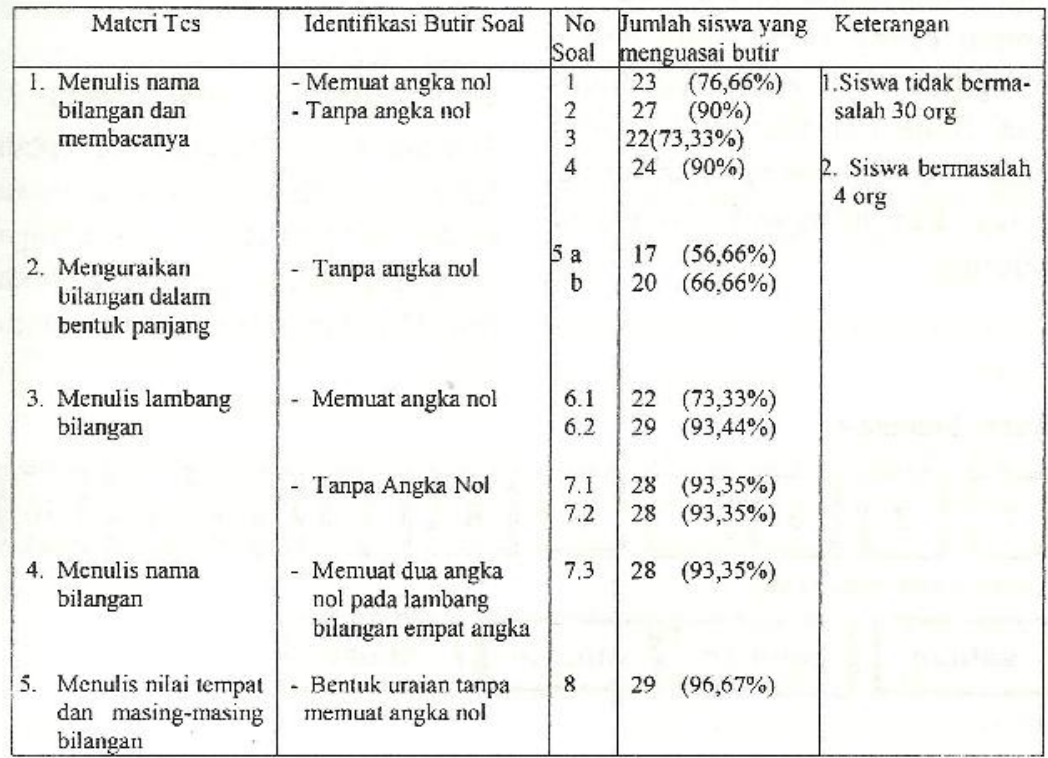


Hasil temuan dan pemantauan pra observasi di atas terlihat bahwa penguasaan siswa pada konsep bilangan dan nilai tempat secara verbal sudah baik namun masih kurang untuk pemahaman yang divisualisasikan, khususnya menulis nama bilangan yang memuat angka nol.

\subsubsection{Pelaksanaan Tindakan (Ac- tion)}

Tindakan disusun berdasarkan perencanaan yang telah disepakati guru dengan peneliti dengan memberikan remedial, observasi perilaku siswa, dan angket sikap siswa terhadap pembelajaran matematika bagi empat orang siswa yang belum menguasai $75 \%$ materi yang diberikan. Remedial dilaksanakan oleh peneliti dengan mempersiapkan alat peraga, kartu bilangan dan kartu nama bilangan.
Tindakan dilaksanakan dengan memberikan remedial $2 \mathrm{x}$ pertemuan dari tanggal 20-21 Maret. Perilaku siswa menerima pelajaran matematika terdapat siswa berperilaku kurang baik. Perilaku siswa kurang baik langsung diberikan bimbingan secara individual, dengan memperhatikan dan menghargai guru sewaktu pembelajaran berlangsung, maupun diluar jam pembelajaran. Membandingkan perilaku siswa yang rajin dan yang tidak rajin, dan menasehati agar jangan suka mengganggu temannya baik di kelas maupun di luar kelas, harus teliti mengerjakan tugas dan hati-hati sehingga diperoleh hasil kerja yang tepat dan benar.

\subsubsection{Refleksi (Post Observasi)}

Suasana kelas sewaktu diberikan ,remedial sudah ada perubahan, siswa merasa senang dengan alat peraga yang digunakan bahkan mereka sewaktu diberi kesempatan maju

\section{Kartu bilangan}
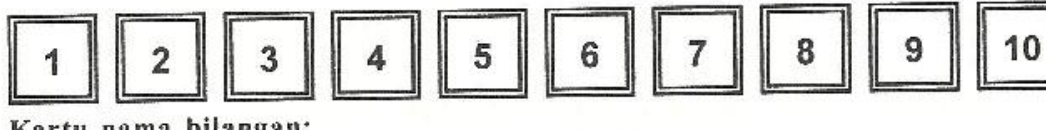

Kartu nama bilangan:

satuan

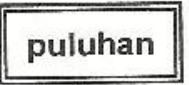

\section{ratusan}

ribuan 
mengerjakan tugas menjawab soal, mereka rebutan untuk maju ke depan untuk menempelkan kartu lambang bilangan maupun kartu nama bilangan

Sikap siswa terhadap pembelajaran matematika sudah bagus mereka bersikap positif terhadap pelajaran yang diberikan. Perilaku siswa mengikuti pelajaran matematika setelah diberikan bimbingan individual sudah menunjukkan perubahan yang cukup baik. Siswa sudah memperhatikan dan meng-hargai guru sewaktu pembelajaran berlangsung maupun diluar jam pembelajaran, mau disuruh menjawab pertanyaan ke depan kelas, tidak mengganggu temannya baik dikelas maupun di luar kelas, dan sudah teliti mengerjakan tugas yang diberikan. Bimbingan dievaluasi pada jam istirahat, dan pada waktu jam pelajaran yang diberikan oleh guru lain.

Setelah diberikan tes khusus pada empat orang siswa bermasalah alhamdulillah hasilnya cukup baik dan sudah ada peningkatan di mana sebelumnya, nilai rata-rata siswa diperoleh 63,75 dan setelah diberi remedial nilai rata-rata 86,25 .

\subsection{Siklus Kedua: Materi Penjumlahan dan \\ Pengurangan}

\subsubsection{Pra observasi (Reconnais- sance)}

Hasil temuan dan pemantauan sewaktu pra observasi menunjukkan bahwa masih ada siswa yang kurang memperhatikan pelajaran yang diberikan, mengerjakan tugas asalasalan bahkan kurang teliti, dan diantara siswa masih ada yang ngobrol dengan temannya, tidak mau mengerjakan tugas di muka kelas, yang bersedia mengejakan tugas di muka kelas jawabannya masih belum tepat. Akhirnya tugas yang diberikan belum selesai sepenuhnya.

Penguasaan siswa terhadap materi belum sepenuhnya dikuasai siswa, walaupun guru sudah berupaya memperbaiki KBM, dengan membawa metode yang sudah berhasil dibawa lagi kesiklus kedua, di mana pembelajaran sudah menggunakan alat peraga yang menarik, serta memberikan latihan pada siswa namun hasil yang diperoleh masih belum memuaskan, bahkan siswa bermasalah lebih banyak dari siklus pertama. Hasil penguasaan materi dan jumlah siswa bermasalah dan tidak bermasalah dapat dilihat pada Tabel 2.

Hasil temuan dan pemantauan pra observasi di atas terlihat bahwa 
Tabel 2. Penguasaan Materi Berdasarkan Persentase Jumlah Siswa

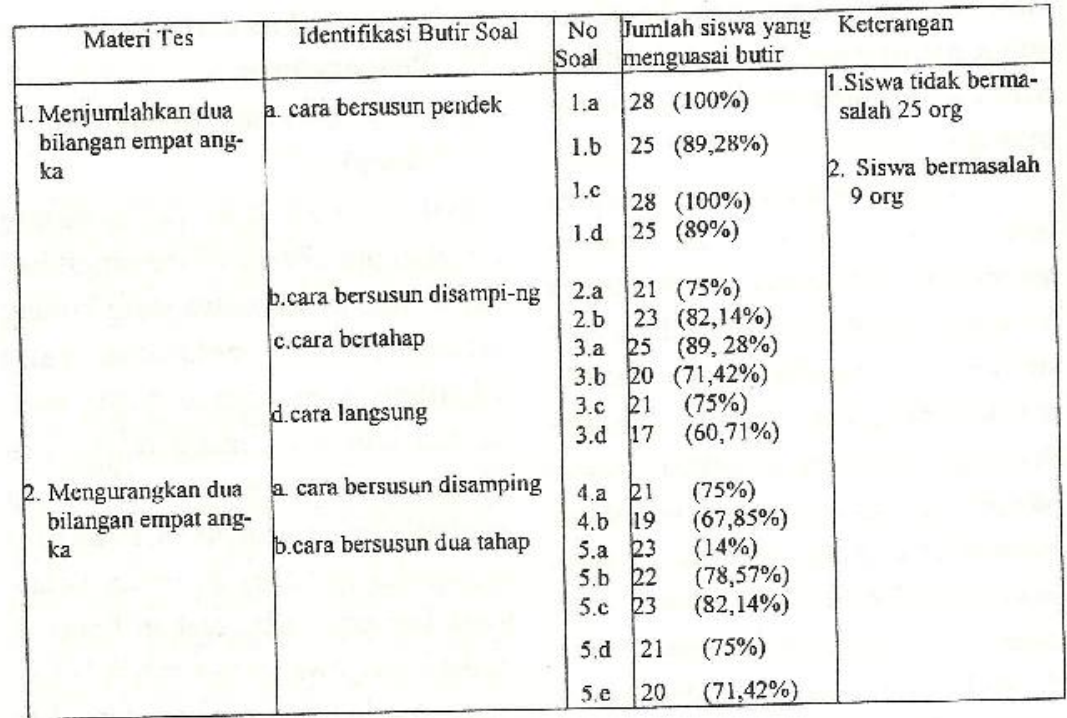

penguasaan siswa pada konsep penjumlahan dan pengurangan sudah baik namun masih ada kekurangan terutama pada penjumlahan dengan cara bertahap lăngsung.

\subsubsection{Pelaksanaan Tindakan (Action)}

Remedial dilaksanakan peneliti dengan mempersiapkan alat peraga kantong nilai tempat bahannya terbuat dari karton dilaksanakan pada tanggal 28 Maret - 3 April dengan $4 \mathrm{x}$ pertemuan :
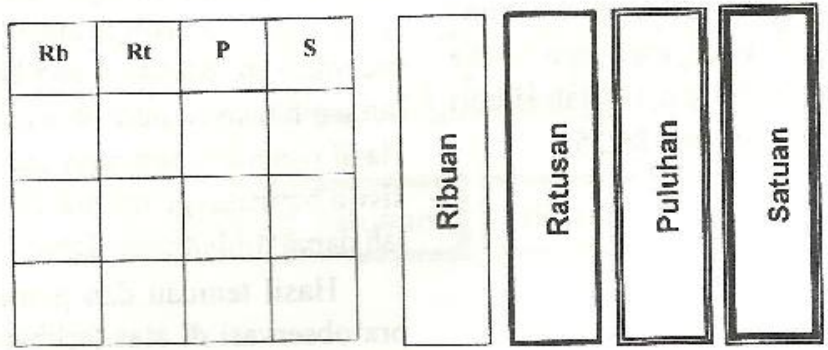
Pendekatan pembelajaran diubah menggunakan model connected, dan penyajiannya menggunakan alat peraga.yang lebih menarik, sehingga siswa lebih aktif dan pembelajaran lebih bermakna dan terlihat siswa senang menerimanya. Pengelolaan kelas yang dilakukan, dengan memberikan, penugasan, tanya jawab, melalui pendekatan pembelajaran.

Perilaku siswa kurang baik langsung diberikan bimbingan secara langsung pada siswa yang kurang memperhatian diberi tugas menjawab pertanyaan, siswa yang suka ngobrol, duduknya disuruh ke depan dekat meja peneliti, siswa yang tidak mau maju kedepan, dibimbing sambil dibantu menjawab pertanyaan oleh peneliti.

\subsubsection{Refleksi (Post Observasi)}

Suasana kelas sewaktu diberikan remedial sudah ada perubahan, siswa mulai perhatian, dan senang dengan alat peraga yang digunakan bahkan mercka sewaktu diberi kesempatan mengerjakan tugas menjawab soal, mereka lebih hati-hati, dan sudah berani mengajukan pendapat bila temannya mengerjakan tugas yang keliru. Setelah diberikan tes khusus pada sembilan orang siswa bermasalah alhamdulillah hasilnya cukup baik dan sudah ada peningkatan di mana sebelumnya nilai rata-rata diperoleh 57,77, dan setelah diberi remedial nilai rata-rata 85,28 .

\subsection{Siklus Ketiga: Materi}

Bilangan Bulat sampai dengan $10.000,00$ dan Perhitungan

Uang

\subsubsection{Pra observasi (Reconnais- sance)}

Hasil temuan dan pemantauan sewaktu pra observasi menunjukkan bahwa masih ada siswa yang belum benar menghitung nilai mata uang, suasana kelas pada saat proses pembelajaran berlangsung cukup tenang, walaupun kadang-kadang diantara siswa ada yang suka bicara dengan temannya, keluar masuk kelas sewaktu pembelajaran berlangsung, dan temannya yang lain juga ada yang mengikutinya.

Sewaktu mengerjakan tugas dan tes pada pembelajaran berlangsung kekeliruan terbanyak ditunjukkan siswa antara lain, pada materi menentukan uang tukar Rp 5.000 dengan uang $R p 500$ penguasaannya hanya $45,45 \%$. Hasil penguasaan materi dan jumlah siswa yang bermasalah dan tidak bermasalah dapat dilihat pada Tabel 3 .

Secara umum penguasaan siswa terhadap materi ini belum sepenuhnya dikuasai siswa, walaupun 


\section{Tabel 3. Penguasaan Materi Berdasarkan Persentase Jumlah Siswa}

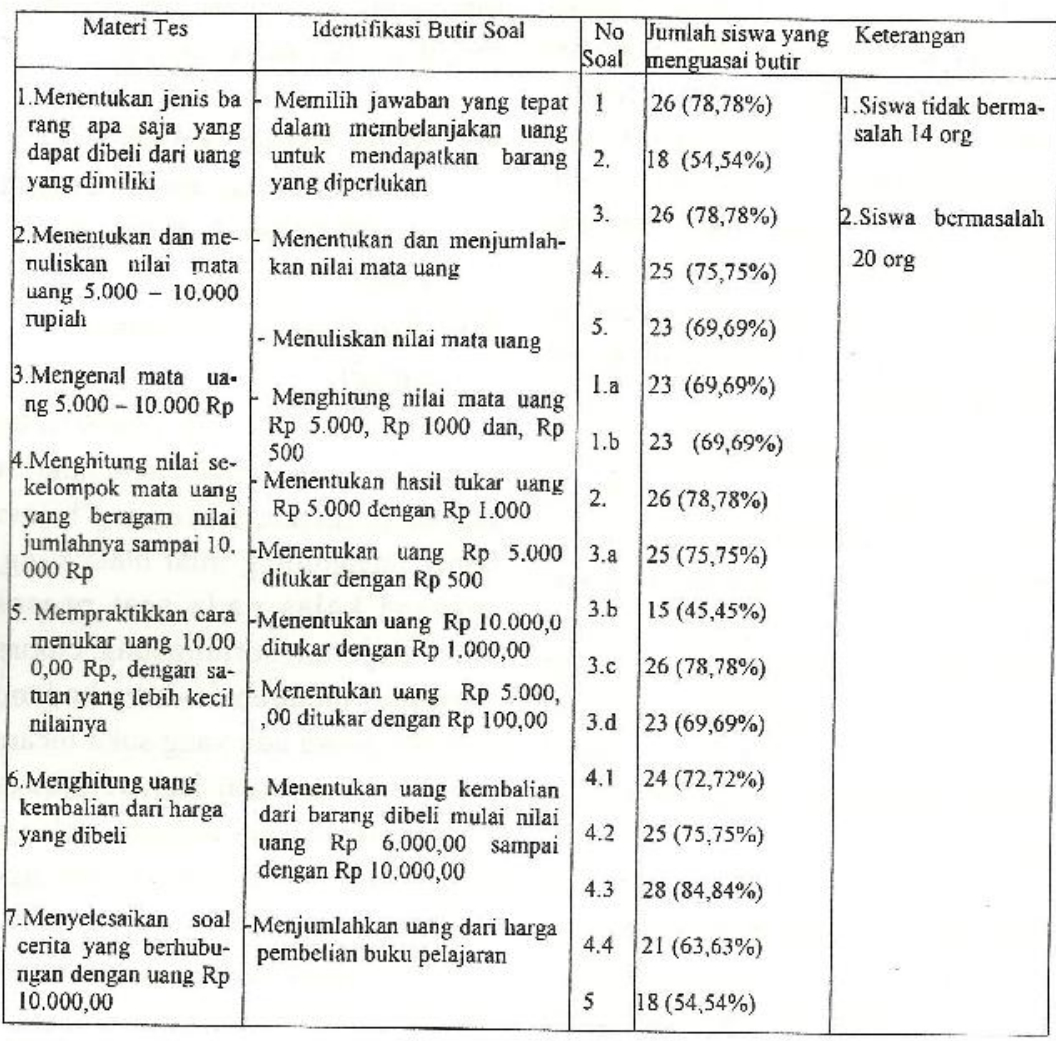

guru sudah berupaya memperbaiki KBM, dengan menggunakan alat peraga dengan gambar-gambar menarik, serta memberikan latihan pada siswa namun hasil yang diperoleh masih belum memuaskan baik dari guru, maupun kolaborator, dan siswa itu sendiri, siswa bermasalah pada siklus ketiga ini sebanyak 20 orang.
Pengamatan kolaborator menunjukkan bahwa masalah ini muncul bukan hanya dari segi siswa namun juga dari segi guru.Dari segi guru berkaitan dengan pendekatan pembelajaran khususnya dari segi penilaian yang dilakukan guru, di mana siswa bermasalah tidak ditin- 
daklanjuti, kemudian memindahkan pertanyaan pada siswa lain.

\subsubsection{Pelaksanaan Tindakan (Action)}

Peneliti merubah pendekatan pembelajaran yang lebih menarik, dan bervariatif agar tidak membosankan, dengan menugaskan siswa secara kelompok melalui tutor sebaya dan dibimbing langsung oleh peneliti, dan kolaborator.

Tindakan dilaksanakan oleh peneliti dengan membagi siswa dalam kelompok terdiri dari empat sampai lima orang siswa.Tindakan dilaksanakan pada tanggal 25 April. Suasana kelas sewaktu diberikan tindakan sudah ada perubahan, siswa terlihat senang dan penuh perhatian, dengan cara kerja kelompok ini, mereka aktif juga mengemukakan pendapatnya walaupun kadangkadang jawabannya belum tepat. Hasil kerjanya dibahas secara klasikal. Siswa bermasalah langsung dibimbing, sampai benar menjawab pertanyaan yang diberikan.

\subsubsection{Refleksi (Post Observàsi)}

Setelah diberikan tes khusus pada duapuluh orang siswa bermasalah alhamdulillah hasilnya cukup baik, bimbingan diberikan secara klasikal. Namun masih ada dua orang siswa yang perlu diberikan bimbingan individual, karena hasilnya tidak sesuai dengan kriteria yang ditentukan. Di mana sebelumnya nilai rata-rata diperoleh 45,53 , dan setelah diberi remedial nilai rata-rata 82,67. Hasil tes dari dua siswa setelah remedial 67,5 , pada akhir bimbinganl hasil tesnya memperoleh skor 92,5 sudah memenuhi kriteria yang ditentukan bersama.

Khusus bagi dua orang siswa yang masih bermasalah langsung diberi bimbingan individual dengan menyiapkan langsung uang Rp 50, Rp $100, \operatorname{Rp} 500, \operatorname{Rp} 1000, \operatorname{Rp} 5.000$, dan uang $R p$ 10.000. Siswa langsung mempraktikkan perhitungan uang tersebut. Sedangkan sikap siswa terhadap pembelajaran matematika sudah bagus karena pada umumnya mereka bersikap positif, dan menganggap bahwa mempelajari matematika itu penting, agar tidak dibohongi orang.

\subsection{Siklus Keempat : Perkalian dan Pembagian}

\subsection{Pra observasi (Reconnais-} sance)

Kegiatan PBM dilaksanakan pada pertemuan keduapuluhdua tanggal 1 Mei. suasana di kelas cukup tenang. Materi sudah sesuai dengan kurikulum, hasil tes yang diikuti sebanyak tigapuluhempat siswa menunjukkan, kesalahan yang 
terbanyak pada materi membagi bilangan tiga angka dengan bilangan satu angka dengan cara bersusun panjang di kuasai $34,48 \%$. Hasil penguasaan materi dan jumlah siswa yang bermasalah dan tidak bermasalah dapat dilihat pada tabel 4 .

Hasil temuan dan pemantauan pra observasi di atas terlihat bahwa penguasaan siswa pada konsep

\section{Tabel 4 Penguasaan Materi Berdasarkan Persentase Jumlah Siswa}

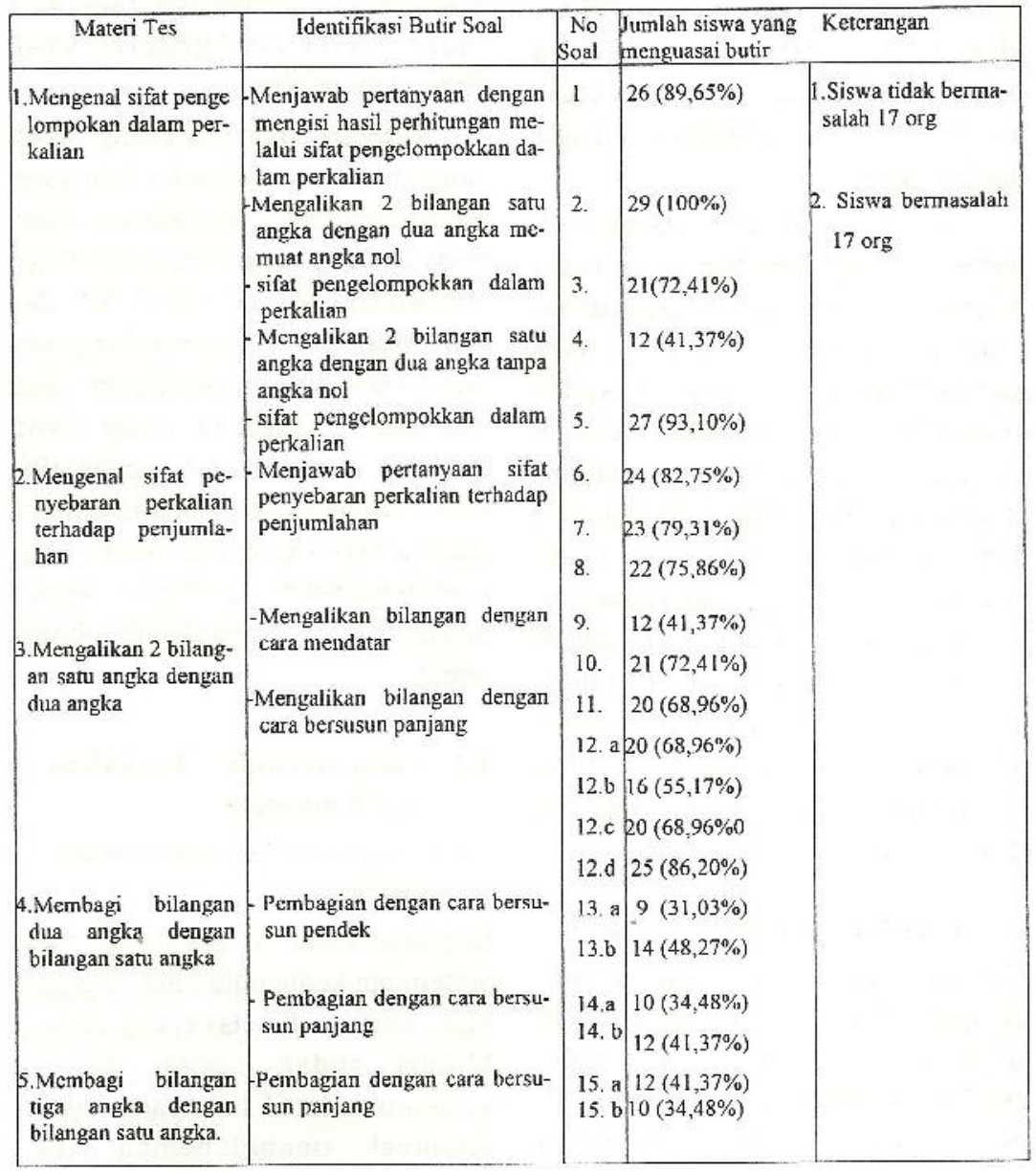


perkalian dan pembagian, masih ada kekurang terutama pada materi pembagian dengan cara bersusun pendek. Hal ini dapat terlihat dari hasil tes formatif dan pemberian tugas menjawab pertanyaan dalam proses pembelajaran.

\subsubsection{Pelaksanaan Tindakan (Action)}

Guru kembali menggunakan model tutor sebaya yang sudah berhasil dilakukan pada siklus terdahulu, mengingat materi ini dianggap sulit oleh siswa, kalau tidak diantisipasi sejak awal, bisa membawa dampak negatif pada siswa. Untuk ini kami sepakat mengadakan remedial, aktivitas siswa dalam PBM makin membaik, siswa sudah berani ke muka kelas, memperhatikan penjelasan guru. Secara umum penguasaan siswa terhadap materi belum sepenuhnya dikuasainys, walaupun guru sudah berupaya memberikan perbaikan $\mathrm{KBM}$, siswa bermasalah sebanyak tujuhbelas siswa.

Hasil pengamatan dalam KBM masalah ini muncul dari siswa, dan guru. Untuk itu guru perlu memberikan pendekatan pembelajaran yang lebih menarik, sehingga siswa lebih aktif dan pembelajaran lebih bermakna dan siswa senang menerimanya. Kesepakatan dengan kolaborator setelah praobservasi memutuskan agar hasil belajar siswa bermasalah perlu ditindak lanjuti agar siswa tidak mengalami hambatan pada materi berikutnya, demikian pula dengan perilaku, dan sikap siswa perlu diberikan penilaian. Pendekatan pembelajaran yang tepat menarik, bervariatif, perlu diberikan agar pembelajaran tidak membosankan.

Pembelajaran kembali menggunakan pendekatan model connected. Hipotesis tindakan jika pembelajaran matematika dirancang menggunakan prosedur instruksional secara fleksibel, pendekatan terpadu model connected, dengan menggunakan alat peraga disertai siklus perbaikan secara berkesinambungn maka diduga dapat meningkatkan hasil belajar matematika.

\subsubsection{Refleksi (Pasca Observasi)}

Tindakan dilaksanakan pada tanggal, 8 Mci setelah diberikan tes khusus pada tujuhbelas orang siswa bermasalah alhamdulillah hasilnya cukup baik dan sudah ada peningkatan di mana sebelumnya nilai ratarata diperoleh 45,29 , dan setelah diberi remedial nilai rata-rata 81,18 . Sedangkan sikap siswa terhadap pembelajaran matematika sudah bagus karena mereka bersikap positif pada pelajaran matematika Perilaku siswa sudah banyak perubahan kalau dibandingkan mulai dari siklus 
pertama sampai terakhir, kalau diantara siswa ada yang suka mengganggu temannya, membuat keributan, kurang memperhatikan penjelasan guru, ada yang bawa mainan, tidak mau disuruh menjawab pertanyaan di kelas, akhir kegiatan ini tidak ditemukan lagi.

Hasil evaluasi belajar siklus pertama sampai dengan siklus keempat, dan tes hasil belajar sudah menunjukkan peningkatan yang cukup memuaskan, begitu pula dengan penilaian sikap dan perilaku siswa mengikuti pelajaran matematika. Demikian pula dengan tes diagnostik awal, rata-rata skor diperoleh 5,199 dan tes diagnostik akhir sudah menunjukkan peningkatan yang cukup siqnifikan yakni rata-rata skor diperoleh 8,596.

\section{Simpulan dan Saran}

\subsection{Simpulan}

Berdasarkan temuan-temuan di atas secara ringkas dapat disimpulkan bahwa: Hasil belajar matematika siswa meningkat, setelah setiap topik pembelajaran diberikan asesmen diagnostik berupa penilaian tes, remedial, penilaian sikap, dan observasi perilaku siswa mengikuti pembelajaran matematika.

\subsection{Saran}

Pertama, para siswa hendaknya lebih menyadari peran dan tanggung jawabnya sebagai pelajar yang ingin memiliki pengetahuan, dimana pelajaran matematika menuntut cara belajar yang berbeda dengan pelajaran lain. Belajar matematika menuntut keterlibatan dan keteraturan yang ketat, dan keunggulan matematika terletak pada ketepatan dan ketelitian dalam memecahkan berbagai permasalahan. Oleh karena itu ketelitian dan keberhati-hatian mutlak diperlukan dalam mengerjakan soal matematika baik di sekolah maupun dalam mengerjakan pekerjaan rumah.

Siswa hendaknya jangan merasa puas kalau mendapat nilai 75 , siswa harus belajar dari kesalahan dan kekurangan pahaman yang segera di atasi agar jangan menjadi hambatan di masa yang akan datang. Tes harian dan tes setiap topik pembelajaran, yang sering diberikan guru, apapun hasilnya hendaknya jangan ditafsirkan hanya untuk mengukur tingkat penguasaan materi yang di pelajari, tetapi juga mencari kelemahan dan kekurangan yang dimiliki untuk segera di atasi.

Kedua, guru tetap memiliki peranan utama dalam kegiatan pembelajaran, tugas guru bukan hanya mengajarkan semua materi seperti yang tertera pada kurikulum 
tetapi juga harus mengetahui apakah materi yang diajarkan sudah diketahui dan dikuasai oleh siswa. Telah dijelaskan bahwa di kelas siswa memiliki ksmanpuan yang berbeda, oleh karena itu guru dituntut untuk menguasai teori dan keterampilan keguruan serta memahami secara mendalam karakteristik siswa, dan bcrusaha untuk lebih mengenal siswa yang diajarnya, dengan menyajikan pembelajaran melalui penggunan benda-benda model yang konkret sebagai medianya. Guru hendaknya secara rutin mengadakan tes di kelas, tes diberikan bukan hanya mengukur keberhasilan siswa tetapi juga untuk mengetahui kelemahan, dan hambutan yang dialami siswa. Bagi siswa yang mengalami masalah ditindak lanjuti dengan memberikan penilaian tidak hanya segi kognitif, tetapi juga non kugnitif sehingga siswa akan merasakan manfaat dari tes yang diberikan.

Ketiga, Depdiknas perlu memberikan penyegaran dan pengetahuan khususnya tentang pelaksanaan asesmen diagnostik mulai dari penulisan, instrumen baik tes, maupun non tes. Serta penyempurnakan pendekatan pembclajaran yang selama ini dilaksanakan dengan memasukkan sebanyak mungkin materi cakupan yang diajarkan terintegrasi dengan mata pelajaran lain (pembelajaran terpadu). Perangkat tes dan non tes yang dilaksanakan dalam penelitian ini masih berpeluang untuk disempurnakan. Olch sebab itu, perangkat instrumen ini perlu dikalibrasikan dengan pengambilan sampel yang lebih banyak, dan representatif serta disosialisasikan sehingga dapat dikembangkan dan digunakan oleh semua sekolah baik secara lokal maupun Nasional. Kegiatan ini dapat dilakukan dengan memberikan pelatihan kepada guruguru SD melalui KKG, diskusi, pelatihan, dan seminar.

Keempat, I embaga Pendidikan Tenaga Kependidikan seperti PGSD sebagai lembaga pendidikan yang memproduk calon guru SD, perlu adanya pembentukan keterampilan berkomunikasi lebih awal dan terintegrasi dcngan kegiatan program pengalaman lapangan dan simulasi atau latihan mengajar bersama teman sebaya, dalam pclaksanaan mata pelajaran yang menyangkut proses pembelajaran, sampai dengan sistem evaluasi.

Perlu memasukkan asesmen diagnostik sebagai salah satu materi kajian penilaian disamping itu mereka juga perlu mensinergikan mata kuliah evaluasi pengajaran dalam kerangka penilaian diagnostik, dengan demikian para lulusan PGSD, tidak asing dengan pelaksanaan asesmen 
diagnostik ini. Untuk itu dosen PGSD pada FKIP hendaknya menjadi model dan memberi peluang yang memadai bagi kegiatan-kegiatan pengkajian dan penelitian yang memungkinkan para mahasiswa mengaktualisasikan, memanfaatkan dan menumbuhkembangkan potensinya sebagai guru SD. Hal ini harus diimbangi oleh penguasaan materi yang tuntas dan pemahaman tentang berbagai teori helajar yang memadai.

\section{Pustaka Acuan}

Aiken, Lewis R.1997. Psychological Testing and Assesment. London: $\Lambda$. Viacom Comprany

Anghileri, Julia. 1995. Childrens Mathematical Thingking in the Primary Years. London: Cassell, Wellinn Mouse.

Anonim. 1996/1997. Materi Pokok Pembelajaran Terpadu, Jakarta: Depdikbud.

Bell Gradler Margaret E. 1994. Belajar dan Membelajarkan, Jakarta : Pt Raja Grafindo Persada.

Bredekamp Sue. 1987. Developmentaly Appre Priate Approoach In Early Children Program Serving Children Prom Birlh Through Age 8. Naeyc : Publishing Inc

Bell. Frederick H. 1981. Teaching and Learning Mathematics in Scondery School. New York: Printed in the United States of Amerika.

Carnoy, Martin. 1995. International Economies of Education, USA: ELS Eversains LTD.

Collin, Gillian and Dixson, Hazel. 1991. Integrated Learning Planned Curriculum. New Yersy: Unit Gosford Book Sheif Publishing.

Crutchfield D. Krech, R. S., and Ballachey, E. L. 1988. Individual in Sociaty. Tokyo: McCraw-Hill Book Company.

Davies Ivor K. 1971. The Management Of Learning London : Mc Graw Hill Book Company Lemited

Djamarah, Syaiful Bahri. 2000. Guru dan Anak Didik dalam Interaksi Edukatif. Jakarla: Renika Cipta.

Ebel, Robbet L. 1979. Essentials of Educational Measurement. New Jersy: Prentice-Hall Inc.

Edwarl Anne, Kninght Peter. 1994. Effektif Early Yeary Education. Hongkong: Grafhicraft.

Ecclestone, Kethryn. 1996. How To Assess The Vocational Curriculum. Iondon: Kogan Page.

Feldman, Robbert S. 1989. Esseniuls of Understanding Psychology. New York: McCraw-Hill Book Company.

Fisbein Marten and Ajzen, Iccr. 1997. Belief Attitude Intention \& Behovior, 
London: Addison Wesley Publishing.

Fogarty, Robbin. 1991. The Mindful School How to Integrated the Curricula. Amerika: Publishing Palatine, Lilinois.

Gagne, Robert M. 1977. The Conditions of Leurning. New York: Holt, Rinchart and Winston.

Gronlund, 1990, Measurment And Evaluation Inteaching : New York : Mac Milian Publishing Co

Higgens, John L. 1983. Mathematics Teaching and Learning. Worthington, Ohio: Charles A Jones Pub., Co.

Hodoyo, Herman. 1990. Strategi Mengajar Belajar Matematika. Malang: IKIP Malang.

Hadoyo, IIerman. 1998. Pengembangan Kurikulum Matematika, Peaksunaannya di Depan Kelas. Surahaya: Usaha Nasional. Malang: IKIP Malang.

Kurikulum Pendidikan Dasar, Landasan Program dan Pengembangan. 1994. Jakarta : Depdikbud.

Laporan Pclaksanaan Eblanas Sd/Mi. 2000, Nilai Rata-rata Ebtanas Rayon Benjarbaru, Banjarbaru : Kanwil Depdiknas

L. Linn, Robbert, Gronlund Norman, E.1995. Measurement And Assesment in Teaching. New Jersy: Prentice Hall. Inc.

McKeachie. 1994. Teaching Tips America. D.C.: Health and Company.

Mullis, L Marten, M Gonzales, E Gregory, K Garden, R. O. Connor, K. 2000. TIMSS-R 1999 Internasional Mathematics Report, Beston : Lynch School Of Education

Nitko Antony J. 1996. Educational Assesment of Student. New Yersy: Prentice Hall Inc.

Pusat Penilaian Pendidikan. 2003. Kemampuan Dasar Hidup, Jakarta : Puspen Diknas.

Romiszowski, A.. J. 1981. Designing Intructional System. New York: Kogan Page.

Ruseffendi, E. T. 1988. Pengantar Kepada Membantu Guru Mengembangkan Kompetensinya dalam Pengajaran Matematika untuk Meningkatkan CBSA. Bandung: Tarsito.

Syamsudin Makmun. 2003. Psikologi Pendidikan, Bandung: Rosda Karya Undang-undang Ki No 20, 2003 Sistem Pendidikan Nasional Bandung :

Citra Umbara

Tessmer, Martin. 1995. Planing and Contructing Formatif Fvaluation, London: Biddes LTD, Guildford and Kings Lys.

Usman. Moh Uzer., Setiawati Lilis. 1993. Upaya Optimalisasi Kegiatan Belajar Mengajar. Bandung: Remaja Rosda Karya. 